\title{
Evaluation of Growth Area Foliar Red Tomato Crop Using Markov Chains
}

\author{
Luz E. Marín Vaca1, Miguel Aguilar Cortes¹, Oscar G. Villegas Torres², Nadia Lara Ruiz, \\ Martha Lilia Domínguez Patiño ${ }^{3}$ \\ ${ }^{1}$ Engineering and Applied Science Postgraduate School, University of Autonomous Morelos State, Morelos, \\ Mexico \\ ${ }^{2}$ Faculty of Agricultural Sciences, University of Autonomous Morelos State, Morelos, Mexico \\ ${ }^{3}$ Faculty of Chemical Sciences and Engineering, University of Autonomous Morelos State, Morelos, Mexico \\ Email:maguilarc@uaem.mx
}

Received 2 June 2016; accepted 26 June 2016; published 29 June 2016

Copyright (C) 2016 by authors and Scientific Research Publishing Inc.

This work is licensed under the Creative Commons Attribution International License (CC BY).

http://creativecommons.org/licenses/by/4.0/

c) (i) Open Access

\section{Abstract}

The importance of evaluating the leaf area in red tomato plants aims to determine the growth and development of crops established two production cycles, spring-summer and autumn-winter to compare the influence of temperature on the growth of leaf area. Repeated, weekly samples were taken by identifying the week and determining the growth and leaf area development using Markov chains, using an array of transition to describe and represent in a flowchart the finite number of physiological States. With the analysis in the steady state process and applying the equations of odds, we get that leaf area growth is established from the seventh week shown in the first cycle (C1) with the chance of $0.266,0.264$ and 0.263 , in the last two weeks. It was observed an increase of $6 \%$ in the cycle autumn-winter cycle compared spring-summer.

\section{Keywords}

Leaf Area, Tomato and Markov Chains

\section{Introduction}

By simple be the development and growth of tomato plant there are links of other variables that allow such as: temperature, sunlight, nutrients and substrate or soil. Mexico has a great diversity of climates by what these crop yields vary depending on the level of applied technology (greenhouses, mesh-shadow or Mac), conditions of light, temperature and substrate or soil in which to develop [1]. Cultivation is determined by the direction of growth, to assess the growth of leaf area weekly. To determine the growth of this, you may experience through 
two crop cycles; therefore sampling should be held sequentially with trials repeated weekly, which would allow the application of the model of Markov chains. Paegelow mentions that Markov chains simulate the prediction of the State of a system at a time determined from two from States, i.e. that does not consider the descriptive, and explanatory variables, but it is based solely on the analysis of the internal dynamics of the system. In the study of the growth of leaf area apply Markov chains, determining the functions of the variables which link the growth of tomato in its phenological stages, established by weekly surveys on the development of plants, so it is essential to establish a transition matrix, this being a stochastic process used to study phenomena from an initial state, passing through a sequence of States, where a particular State transition occurs according to a certain probability [2]. Above, are carried out two experimental trials in the cycles of production, spring-summer and autumn-winter determining growth leaf area in red tomato type "Saladette" under greenhouse conditions.

\section{Approach to the Problem}

A Markov chain is a series of events, in which the probability of an event occurring depends on the previous immediate event. This type of chains have memory, "Remember" the last event and this determines the possibilities of future events, this dependence distinguishes the series of independent events Markov chains [3].

Growing vegetables in each of the events of growth has memory, i.e., each event's growth is a sequential event in the crop phenological stage (vegetative, flowering and fruiting). The red tomato presents a series of consecutive events in each of the stages of growth of leaf area, which through the process of Markov chains recorded these weekly to establish probabilistic analysis of steady state.

\section{Justification}

Within the development and growth of tomato involved a finite number of variables and within these, one of the most important is the leaf area, that is why, your analysis is indispensable, in order to determine the mass dry leaf area or the growth of the fruit; a model of Markov chains represents any of the variables, by means of a transition matrix we will represent this model, and thus be able to determine the optimal time of growth.

\section{Objective}

Evaluating probabilistic analysis of growth of leaf area in two production cycles of certain red tomato "Saladette" type with Markov chains in protected conditions.

\section{Methodology}

The pilot phase was conducted in the greenhouse for agricultural production in the Experimental field of the Faculty of Sciences agricultural of the Autonomous University of the State of Morelos; they were two crop sowings during production cycles (November 2014) autumn-winter and spring-summer (June 2015).

Red tomato seedlings were determined "Saladette" type produced in trays of polyethylene of 200 cavities, which was transplanted at a density of 16 plants $\mathrm{m}-2$, two plants per each bag (16 L capacity) with red tezontle substrate. The Fertigation was eight irrigation during the day, with a nutrient solution of Steiner [4] modified.

The experimental design was completely randomized with repeated weekly samplings with destructive variables. We assessed aspects related to the growth of plants, specifically the leaf area; this variable was obtained through 16 weekly plant by sampling during each cycle.

Results were statistically examined through an analysis of variance and Tukey $(\alpha \leq 0.05)$ for the separation of means, using the program SAS 8.1 [5].

To determine the stable state of leaf area in tomato plants by average weekly obtained through an application of Markov chains transition matrix.

\section{Results}

Plant growth is highly related to the temperature and species-specific allows development and their different physiological variables. However, Ho (1995) points out that the ups and downs in temperature affect an imbalance between the vegetative and generative behaviour that takes the floor, having sudden changes in temperature, affecting yields. 
Maintaining an orderly growth flow is of great importance for crops developed under protected conditions, this ensures the performance held in time and space [6]. Two vegetative cycles are approximately linear, being stable in the seventh week growth. The fall-winter cycle maintains an order ascending from the first week until the seventh, reaching its maximum value at the eighth week to stabilize after 63 days after transplant (dat) (Figure 1). The cycle spring-summer after transplantation remains an approximately linear growth up to 49 days, settling down in the seventh and eighth week, to subsequently present a decline light constant (Figure 1). Nunes-Ramirez et al., (2012) says that the first weeks of growing tomato plants are vigorous growth until 80 ddt then reduced to hold itself as increases the formation and fruit production $\left(\mathrm{cm}^{2}\right)$.

Results of separation analyzed with Tukey's test it shows no difference statistically in two production cycles to a significance level of $\alpha \leq 0.05$ in two production cycles being an increase of $6 \%$ of cycle autumn-winter versus spring summer. Andriolo et al., (2003) studied the growth of tomato in greenhouse during the spring and autumn, found that development and growth turned out to be different between stations, resulting in a greater biomass accumulation during the spring in relation to the cultivation of autumn. It exists between growth and development over time and environmental conditions [7].

Markov chains can find the probability that a system is in a State in particular at any given time, i.e., that allows to find the average in the long run or the likelihood of steady state for each State [8]. This predicts us behavior of red tomato leaf area over time, creating a matrix of transition depending on the means to show them in each of the trials of the two crop cycle. To start an analysis of transition, the current state of the growth of leaf area of the two cycles, should know as shown in the following matrix:

To determine the stable state of the leaf area of the two cycles, the following equations are established positioned in the $C_{1}$ :

$$
\begin{gathered}
P\left(C_{1}\right)=P_{11} P_{11}+P_{12} P_{21} \\
P\left(C_{2}\right)=P_{11} P_{12}+P_{12} P_{22} \\
P\left(C_{1}\right)+P\left(C_{2}\right)=1
\end{gathered}
$$

Calculation of the transition matrix or chart of States (Table 1 and Figure 2) to determine the stable state of the leaf area, observed States in the initial cycle diagram:

$$
P\left(C_{1}\right)=P_{11}=0.66
$$

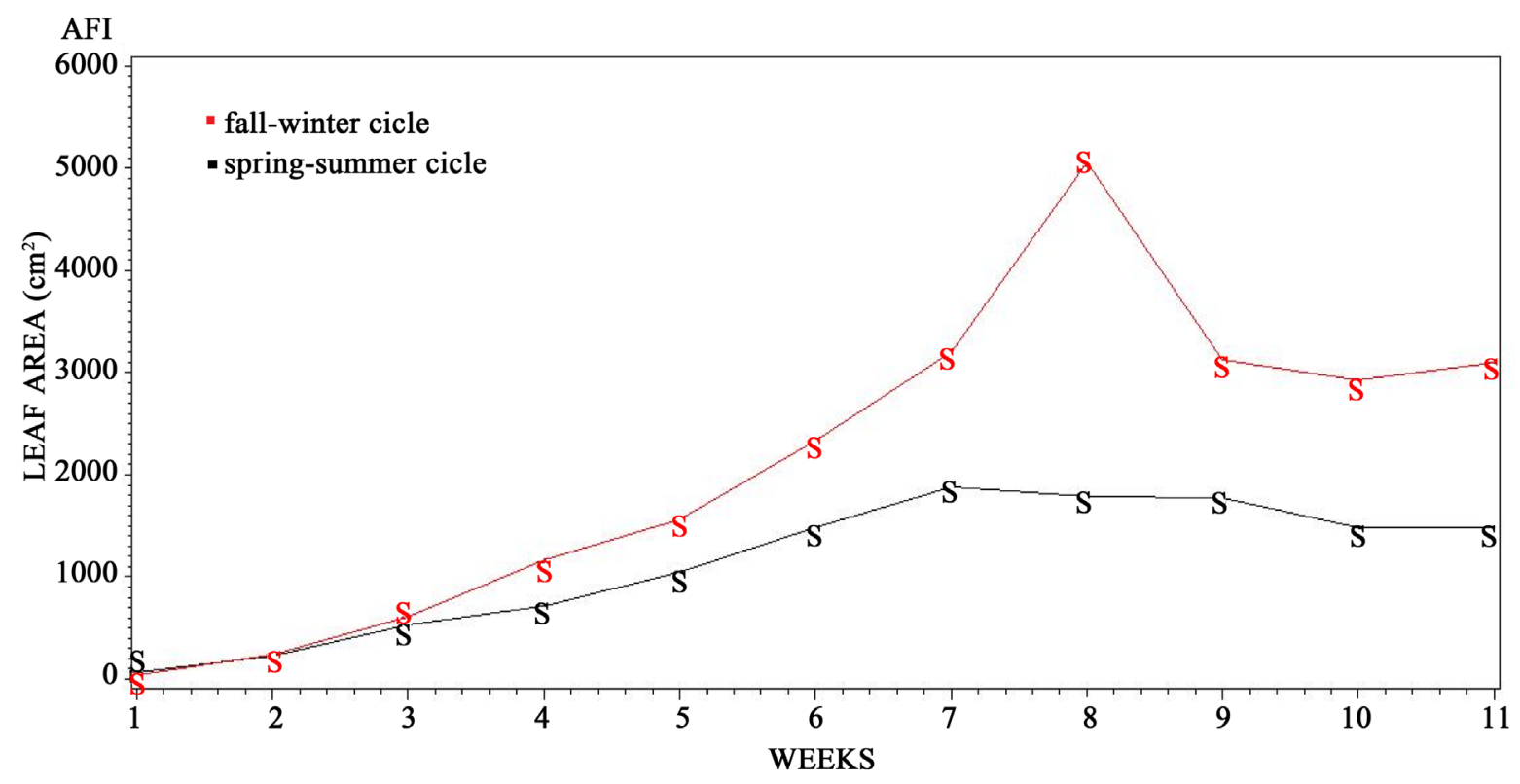

Figure 1. Development of growth of leaf area of tomato red set type "Saladette". 


$$
P\left(C_{2}\right)=P_{12}=0.34
$$

In each of the iterations event probabilities are determined as current Markov chains previous event stored memory.

According to the odds calculate area with equations in nine iterations leaf of each cycle, the establishment of the growth is from the seventh week coinciding with the shown in Table 2, which was determined with stockings to show them on a weekly basis.

In Figure 3, is calculated for the area, steady-state leaf of two seasonal cycles in which is the production of tomato.

Doing an analysis of the probabilities determined by Markov chains with equations (Table 2) for the nine iterations there is a settlement on the growth of leaf area from the seventh week staying at the eighth and ninth (Chart 2).

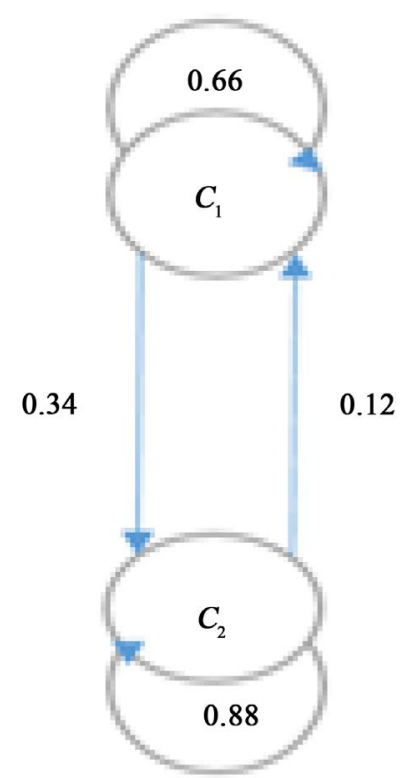

Figure 2. Diagram of states.

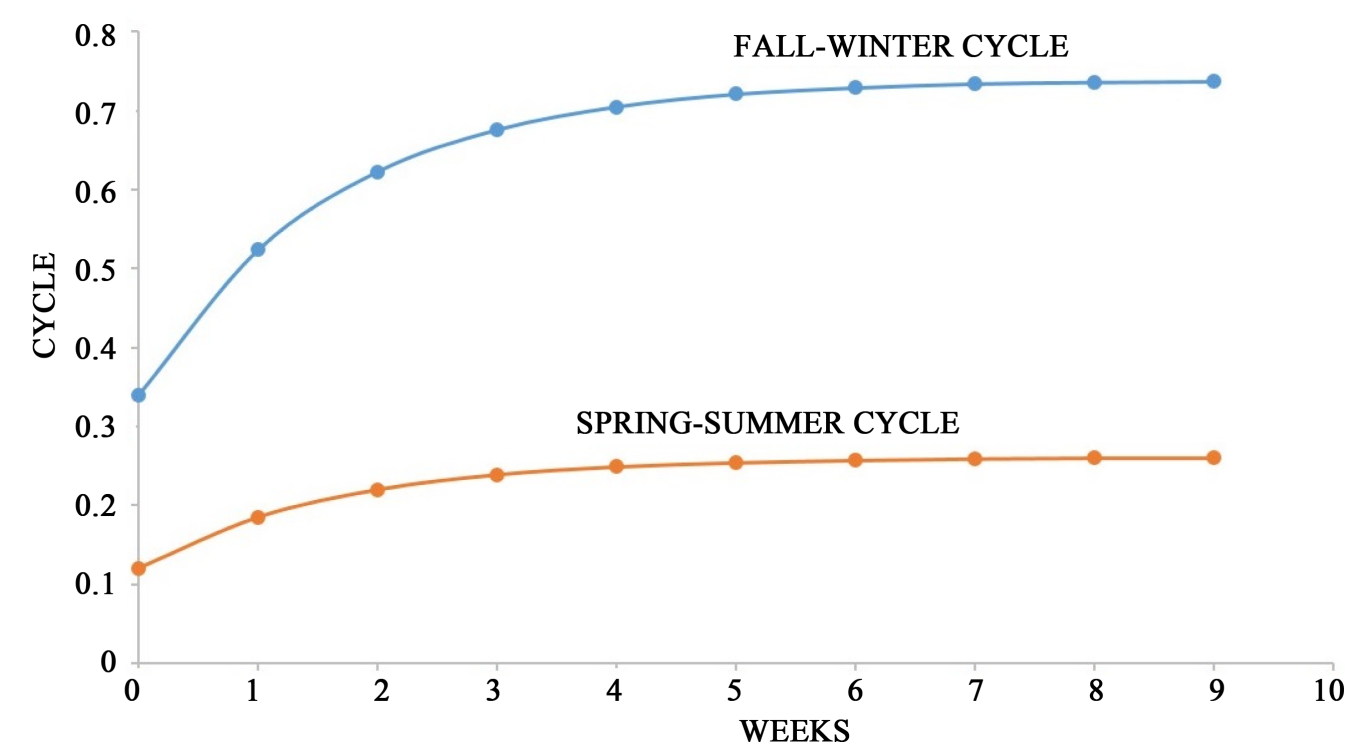

Figure 3. Stable positions in cycle 1 cycle 2 state graph. 
Table 1. Transitionmatrix.

\begin{tabular}{ccc}
\hline & A: & \\
\hline De: & $C_{1}$ & $C_{2}$ \\
\hline$C_{1}$ & 0.66 & 0.34 \\
$C_{2}$ & 0.12 & 0.88 \\
\hline
\end{tabular}

Table 2. Odds of the iterations in the cycle 1.

\begin{tabular}{ccc}
\hline & $P\left(C_{1}\right)$ & $P\left(C_{2}\right)$ \\
\hline Home & 0.66 & 0.34 \\
1 & 0.476 & 0.524 \\
2 & 0.377 & 0.623 \\
3 & 0.324 & 0.676 \\
4 & 0.295 & 0.705 \\
5 & 0.279 & 0.221 \\
6 & 0.271 & 0.729 \\
7 & 0.266 & 0.734 \\
8 & 0.264 & 0.736 \\
9 & 0.263 & 0.737 \\
\hline
\end{tabular}

\section{Conclusions}

An analysis on growth of leaf area with Markov chains, coincides with stockings sampled weekly, and this shows us that they may be useful to generate a settlement in each of the physiological variables.

The equations of state that can be stable as Markov chains perform fast and reliable estimate of leaf area.

To cultivate certain red tomato, the stable state of leaf area arose from the seventh with different temperature conditions.

\section{References}

[1] Costa, P. and Giacomelli, G. (2005) ABC de la producción en invernadero. Productores de Hortalizas. Febrero, 48-50.

[2] Paegelow, M., Olmedo, M.T.C. and Toribio, J.M. (2003) Cadenas de Markov, evaluación multicriterio y evaluación multiobjetivo para la modelización prospectiva del paisaje. Asociación de Geógrafos Españoles.

[3] Gallagher, C.A. and Watson, H.J. (1982) Métodos cuantitativos para la toma de decisiones en administración. McGraw-Hill, Edo de México.

[4] Steiner, A.A. (1961) Un método universal para la preparación de soluciones de nutrientes de una determinada composición deseada. Plant and Soil, 15, 134-154. http://dx.doi.org/10.1007/BF01347224

[5] SAS Institute (1994) The SAS System for Windows. Release 6.10. SAS Institute. Nort Caroline, USA.

[6] Núñez, F., Grijalva, R.L., Macías, R., Robles, F. and Ceceña, C. (2012) Crecimiento, acumulación y distribución de materia seca en tomate de invernadero. Revista Ciencias Biológicas y de la Salud Biotecnia XIV, 3, 25-31.

[7] Andriolo, J.L., Witter, M., Dal-Ross, T. and Godói, R.S. (2003) Crescimento e desenvolvimento do tomateiro cultivado em substrato comreutilização da solução nutritiva drenada. Horticultura Brasileira, 21, 485-489. http://dx.doi.org/10.1590/S0102-05362003000300015

[8] Ho, L.C. (1995) Carbon Partitioning and Metabolism in Relation to Plant Growth and Fruit Production in Tomato. Acta Horticulturae, 414, 396-409. http://dx.doi.org/10.17660/ActaHortic.1995.412.47 


\section{Submit or recommend next manuscript to SCIRP and we will provide best service for you:}

Accepting pre-submission inquiries through Email, Facebook, Linkedin, Twitter, etc A wide selection of journals (inclusive of 9 subjects, more than 200 journals)

Providing a 24-hour high-quality service

User-friendly online submission system

Fair and swift peer-review system

Efficient typesetting and proofreading procedure

Display of the result of downloads and visits, as well as the number of cited articles

Maximum dissemination of your research work

Submit your manuscript at: http://papersubmission.scirp.org/ 